\title{
Why preserve the southernmost fields of Brazil?
}

Por que preservar os campos do extremo sul do Brasil?

\author{
Elisete Maria de Freitas '; Vinícius Leão da Silva " ; Vanessa Liesenfeld "II \\ Aline Viana IV; Ketlin Fernanda Rodrigues v ; Fernanda Bruxel VI \\ Ana Carolina Barzotto VII ; Sabrina Grando Cordeiro VIII ; Maicon Toldi IX \\ Lucélia Hoehne ${ }^{x}$; Eduardo Miranda Ethur ${ }^{\mathrm{XI}}$; Carla Kauffmann ${ }^{\mathrm{II}}$ \\ Shirley Martins Silva XIII
}

\begin{abstract}
In Brazil, grassland ecosystems of the Pampa are restricted to Rio Grande do Sul State (RS) and constitute the largest temperate natural grassland in the world. There are no recent data to indicate how much of these fields was lost in the state, but excursions made in recent years have pointed to a high conversion of native fields into crops. This situation has alerted to the intensification of biodiversity loss and the biological impoverishment of these fields. In view of the above, this study characterizes plant diversity in fields of the southern and western portion of RS. The study was based on publications of recent years that indicate the problems that effectively threaten this diversity. Pampa fields are natural and have a great diversity, constituting a considerable genetic heritage, ensuring the provision of ecosystem services to human populations. The few bioprospecting studies on species from these fields suggest that
\end{abstract}

\footnotetext{
I Universidade do Vale do Taquari, Lajeado, Brazil. elicauf@univates.br

" Universidade do Vale do Taquari, Lajeado, Brazil. suicinivleao@gmail.com

I'I Universidade Estadual do Oeste do Paraná, Cascavel, Brazil. vane_lie@hotmail.com

Iv Universidade do Vale do Taquari, Lajeado, Brazil. alineee_viana@hotmail.com

v Universidade do Vale do Taquari, Lajeado, Brazil. ketyfernanda_@hotmail.com

vi Universidade do Vale do Taquari, Lajeado, Brazil. fbruxel1@universo.univates.br

VII Universidade do Vale do Taquari, Lajeado, Brazil. anabarzottocarol@gmail.com

VIII Universidade do Vale do Taquari, Lajeado, Brazil. sabrina.cordeiro@universo.univates.br

Ix Universidade do Vale do Taquari, Lajeado, Brazil. maicont@universo.univates.br

x Universidade do Vale do Taquari, Lajeado, Brazil. luceliah@univates.br

${ }^{x}$ Universidade do Vale do Taquari, Lajeado, Brazil. eduardome@univates.br

XII Universidade do Vale do Taquari, Lajeado, Brazil. carlakauffmann@univates.br

XIII Universidade Estadual do Oeste do Paraná, Cascavel, Brazil. shirley.silva@unioeste.br
} 
much remains to be discovered and that actions need to be taken to inhibit field destruction. These fields have never been treated as priority areas for conservation, but it is our commitment to reverse this transformation and destruction.

Keywords: Grassland phytophysiognomies; Natural grassland; Pampa Biome

\section{RESUMO}

No Brasil, os ecossistemas campestres do Pampa estão restritos ao Rio Grande do Sul (RS) e constituem a maior área de pastagem natural de clima temperado do mundo. Não existem dados recentes que indiquem o quanto se perdeu desses campos no RS, mas excursões realizadas nos últimos anos têm possibilitado a percepção de que é alta a conversão dessas áreas nativas em lavouras. Tal situação tem alertado para a intensificação da perda da diversidade e do empobrecimento biológico desses campos. Diante disso, o estudo objetivou caracterizar a diversidade vegetal dos campos da metade sul e oeste do RS, baseado em publicações dos últimos anos. Os campos pampeanos são naturais, com grande biodiversidade, constituindo um considerável patrimônio genético, garantindo a prestação de serviços ecossistêmicos para as populações humanas. Os poucos estudos de bioprospecção com espécies desses campos sugerem que muito ainda pode ser descoberto e que é preciso implantar ações para inibir a destruição dos mesmos. Esses campos nunca foram tratados como áreas prioritárias para a conservação, no entanto, é nosso compromisso reverter esse quadro de transformação e destruição.

Palavras-chave: Bioma Pampa; Fitofisionomias campestres; Pastagem natural.

\section{INTRODUCTION}

The southernmost fields of Brazil, also known as subtropical fields, cross the geographical border and extend to Argentina and Uruguay. In Brazil, they are part of Campos Sulinos (Southern Fields), a term used for the fields of the states of Rio 
Grande do Sul (RS), Santa Catarina (SC) and Paraná (PR). The Brazilian Institute of Geography and Statistics (IBGE, 2004) classifies the Brazilian vegetation with respect to biomes. In this proposal, Campos Sulinos, of different phytophysiognomies, are distributed in the Pampa and Atlantic Forest biomes. The Brazilian Pampa is restricted to RS, occurring in the southern and western half of the state and covering an area of $176,496 \mathrm{~km}^{2}$, corresponding to $63 \%$ of the state territory and $2.07 \%$ of the Brazilian territory (IBGE, 2004). It corresponds to the largest temperate natural grassland area in the world (BILENCA; MIÑARRO, 2004). This formation comprises a set of very old ecosystems with their own fauna and flora, great biodiversity, and a considerable genetic heritage, rarely found in other pastoral ecosystems of the planet (QUADROS et al., 2009; VALLS et al., 2009). In addition, species spread through the Pampa fields of Argentina and Uruguay (BOLDRINI, 2009).

Grassland vegetation, with association of $C_{3}$ and $C_{4}$ species, is the most representative vegetation formation of Campos Sulinos, with high number of species and high percentage of ground cover (BOLDRINI, 2009; FREITAS et al., 2009). This coexistence of $C_{3}$ and $C_{4}$ plants is one of the distinguishing features of Campos Sulinos compared to other similar ecosystems (BOLDRINI, 2009). It contributes to the diversity in the area, which exceeds 3,000 plant species, not including bryophytes, lycophytes, and ferns. From the total species mentioned for Campos Sulinos, more than 2,600 species belonging to 89 families occur in Rio Grande do Sul State (RS). Two thousand one hundred and fifty $(2,150)$ species occur in fields of the Pampa biome, while one thousand six hundred and twenty $(1,620)$ species are recorded in fields of the Atlantic Forest biome (BOLDRINI et al., 2015).

The high diversity recorded in these fields reflects the different physiognomies presented, with different floristic compositions, influenced both by geomorphological and climatic characteristics and by land use and management (OVERBECK et al., 2015). These physiognomies are named, according to the same authors, as 'Campos da Campanha' (Campanha Fields), 'Campos dos Areais' (Sandy Fields), 'Campos no Escudo Granítico' (Granitic Shield Fields), 'Campos da Depressão Central' (Central Depression Fields), and 'Campos do Litoral' (Coastal Fields) (HASENACK et al., 2010) (Fig. 1). 
The physiognomy of 'Campos dos Areais', in southwestern RS, stand out from the others for the deep, sandy, permeable, and extremely fragile soils, being exposed to intense erosion processes that result in the formation of sand patches, known as 'areais' (sand deposits with no vegetation cover) (SUERTEGARAY, 1998; SUERTEGARAY et al., 2001). This process of sand formation, called arenization, is natural but its expansion was accentuated from 1970 with the implementation of extensive monoculture. Inadequate land use, intensive grazing, and conversion of these areas to crops, allied to environmental factors such as torrential rainfall, water deficits, and unconsolidated sandy soils, promoted the increase of areas affected by arenization and, consequently, the reduction of plant diversity and primary productivity in these locations (VERDUM, 2004). These factors continue to operate in the Campos dos Areais region, and agricultural expansion has intensified in recent years, without meeting the requirements of current legislation. Associated with agricultural expansion, there is an increased use of agrochemicals.

Figure 1 - Phytophysiognomies of the Pampa fields in the southern and western half of Rio Grande do Sul State, according to Hasenack et al. (2010)

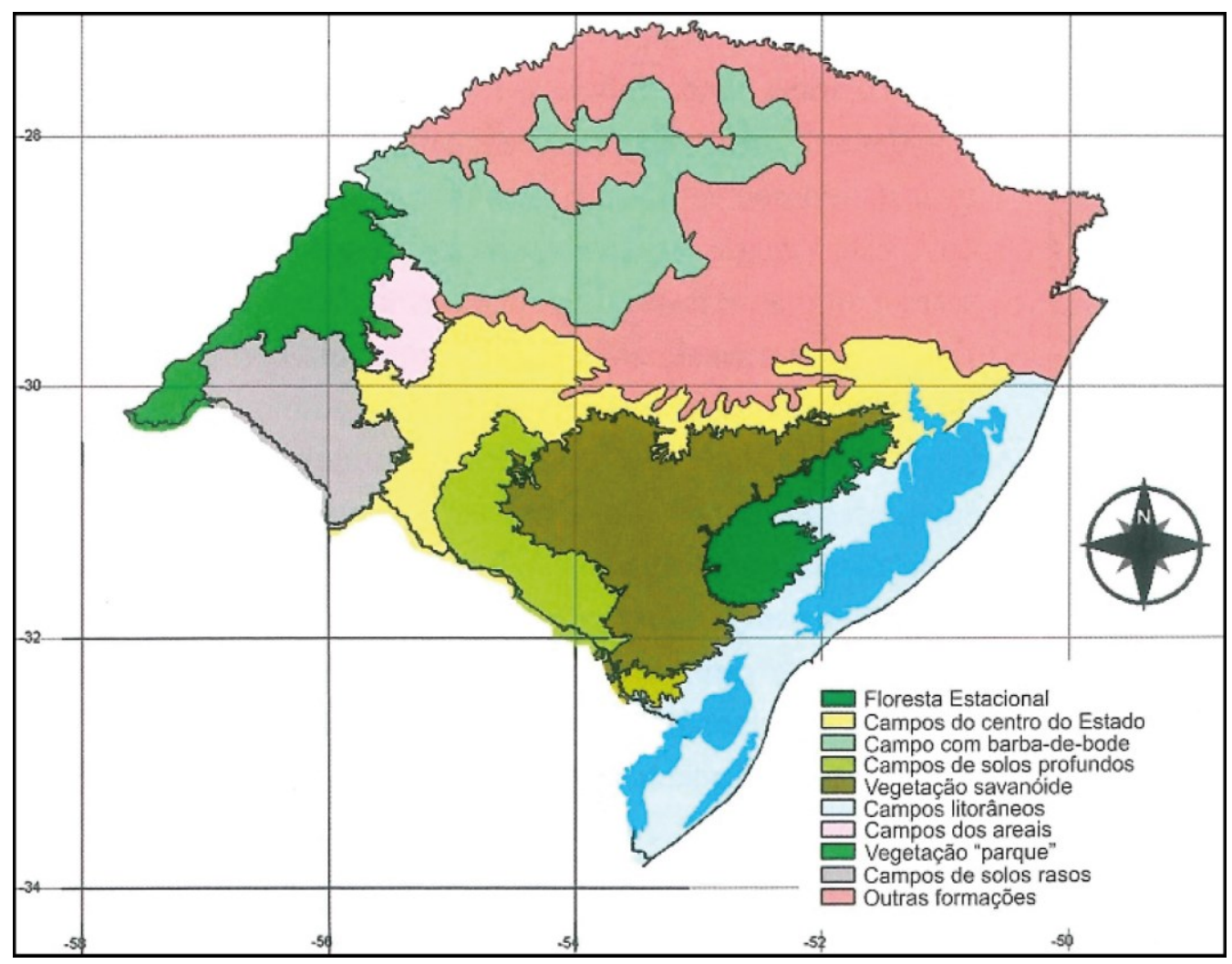


Recent data indicating how much remains of preserved native field in the state are scarce. Hasenack et al. (2007) stated that 51\% of the original grassland vegetation of the entire RS, that is, $64,210.09 \mathrm{~km}^{2}$, had been modified for economic purposes and for urbanization by 2007. Although accepting the use of Pampa fields for fruit and forestry purposes, Nabinger et al. (2009, p. 176) stressed that "still, we would need to preserve at least 9 to 10 million ha with its natural cover. And we don't have that anymore, at least as an area of still intact fields".

Considering that more than a decade has passed since the authors performed these analyses (HASENACK et al., 2007; NABINGER et al., 2009), it is questioned how much remains of preserved fields in RS with the expansion of agriculture in the last years. According to Vélez-Martin et al. (2015), intensification of biodiversity loss and biological impoverishment is undoubtedly a result. But what are we losing regarding genetic diversity? How much could we advance in the production of new medicines while preserving the diversity of these fields, or in pest control from oils, extracts, and natural enemies? Given the above, the present research characterizes plant diversity in the southern and western half of RS, here called Pampa fields or Pampa. The research is based on a compilation of studies published in recent years. Moreover, we indicate the problems that effectively threaten this diversity, awakening to the perception of the need for actions aimed at its recovery and preservation.

\section{MATERIALS AND METHODS}

The study is based on observations from research performed during numerous excursions carried out over 14 years in the Campos dos Areais region, in southwestern RS, especially in the cities of Alegrete, Manoel Viana, and São Francisco de Assis. Research was conducted in these areas both for evaluating the plant community of the fields and for bioprospecting the various native species. Moreover, it is the result of the survey of publications on native fields in the extreme south of Brazil, more specifically in the southern and western portion of the state. 
The climate of this region is characterized as Cfa, that is, the region is located in a temperate/subtropical zone, without a defined dry season, but with hot summers. In this case, the warmest month averages more than $22{ }^{\circ} \mathrm{C}$, with an average annual rainfall of $1400 \mathrm{~mm}$. However, rainfall is poorly distributed, with reduced rainfall periods mixed with heavy rainfall periods, often concentrated in just one day (FREITAS et al., 2009).

The soil is an Ortic Quartzarenic Neosol with sandy texture, sandy silt, and high metal concentrations (STRECK et al., 2008). Due to their great geological and geomorphological diversity, Pampa fields show various classes of soils, which may vary within a few meters. Among them can be cited Neosols, Oxisols, Gleysols, Plantonosol, Argisols, Vertisols, and Chernosols (BOLDRINI et al., 2010).

\section{RESULTS AND DISCUSSION}

\subsection{General characteristics of the vegetation and its defining factors}

Despite the apparent uniformity, Pampa fields hide a surprising biological diversity that has only recently become better known with the intensification of scientific research and the growing interest in conservation in recent years (BENCKE, 2016). These fields, such as those of the Atlantic Forest biome, are natural and older than forests (BEHLING et al., 2009). Throughout their extension, however, they form mosaics with the forests, sometimes raising doubts as to whether their existence is natural or a consequence of anthropic action. Moreover, they can represent a transitional phase in the process of forest expansion over fields. Bauermann et al. (2008) comment that it is common to discuss the predominance of grassland vegetation during the Holocene in the Campanha region of Rio Grande do Sul State.

In their expeditions through Rio Grande do Sul State, Lindman (1906) and Rambo (1956) have noted and quoted in their publications that forests would be able to expand over fields, with field and forest mosaics being a transitional situation for this landscape change. In the search for these answers, palynological analyses performed in sediments from different rural areas of RS (BEHLING et al., 2004; 
BEHLING et al., 2005; BAUERMANN et al., 2008) showed the dominance of herbaceous species from the Middle Holocene to the present. In addition, the same authors point out that the rare pollen grains of forest species recorded during the analyses indicate low tree and shrub diversity. These data prove that the fields in the state are prior to the forests, and that they were dominant in periods of dry-cold or dry-hot climates. Phytogeographic evidence shows that grassland is the oldest vegetation type in the state, with forest expansion being a more recent process resulting from higher humidity conditions due to climate changes (RAMBO, 1956).

Forest expansion over the fields is slow and began about 4,000 years ago, during the second half of the Holocene when the climate became wetter, similar to the current one. It takes place from small populations occurring in deep valleys, next to rivers or slopes, where humidity in the driest periods was sufficient for their survival. In this way, forest massifs were formed in some regions (BEHLING et al., 2004; LEONHARDT, LORSCHEITTER, 2010). An example cited by Behling et al. (2004) is what happened to the araucaria forests in higher lands, which migrated from gallery forests and slowly replaced field areas in the states of Santa Catarina and Paraná about 1000 and 1500 years ago, respectively. It is believed that the same occurred in the fields of the southern and western half of RS, as shown by the study of Bauermann et al. (2008).

Humidity persists to the present day in RS, and is a favorable condition for the continuation of forest expansion. However, it has not been sufficient for forests to dominate the fields, ensuring the predominance of grasslands in much of the territory (BEHLING et al., 2009). This resistance to the advancement of forests is the result of fire and cattle grazing. For Overbeck et al. (2018), the interaction of these two factors is a basic condition for the conservation of southern Brazilian fields, as happens with the North American tallgrass prairie, where they contribute to the maintenance of biodiversity.

In the case of Rio Grande do Sul State, fire became more important in the process of maintaining the fields by preventing forest expansion 7,000 years ago, when the great grazers were extinguished (PILLAR, 2003). The existence of fire during 
this period is evidenced by the occurrence of coal particles in sediments studied by Bauermann et al. (2008), Behling et al. (2004), and Behling et al. (2005). The introduction of cattle and horses in the $17^{\text {th }}$ century, maintained to the present day, has been and continues to be essential for the maintenance of the fields, contributing to their high biodiversity (BEHLING et al., 2009) as long as there is no overgrazing.

Burnings increase species diversity on a local scale (OVERBECK et al., 2015), and these species are adapted to frequent burning and grazing (QUADROS; PILLAR, 2001; OVERBECK; PFADENHAUER, 2007). In turn, fields where there is no fire or grazing often have high dominance of few species of dusky grasses and low diversity of other herbaceous plants that are gradually replaced by forest species (OVERBECK et al., 2009). This dynamic is observed in the fields of the northern half of the state and in the Central Depression region. Nonetheless, studies that prove this forest expansion are unique to the fields of the Atlantic Forest biome, disregarding the Pampa region.

\subsection{Plant diversity in the southernmost fields of Brazil}

In this scenario of resistance to forest expansion and exposure to fire and grazing, several studies show high diversity for the pampeanos fields. Species that compose these fields and other fields of southern Brazil are originated from the Chaco region and the Amazonian and Andean-Patagonian domains. This clearly demonstrates that the present plant community is composed of species of different origins with high diversity of herbaceous species from different families, highlighting grass species (Poaceae). Species of Poaceae constitute the general matrix, dominating the grasslands both in number and in percentage of ground cover. This landscape is thus often permeated by shrubs and subshrubs (CABRERA; WILLINK, 1980; BEHLING et al., 2009; BOLDRINI, 2009; BENCKE, 2016), with the inclusion of river bank forests (BOLDRINI, 2009).

Among studies addressing the largest families, Boldrini (2009) presented data for each of the grassland physiognomies of the southern and western portion of Rio Grande do Sul State. For Deep Soil Fields, the author cited Poaceae (29\%), Asteraceae (11\%), Cyperaceae (7\%), Fabaceae (6\%), and Verbenaceae (4\%) as the richest families. 
For Campos dos Areais, the most numerous families were Asteraceae (24\%), Poaceae (19\%), Fabaceae (8\%), Euphorbiaceae (4\%), Cyperaceae (3\%), and Rubiaceae (3\%). For Campos da Serra do Sudeste (Southeastern Hill Fields), the most numerous families were Poaceae (28\%), Asteraceae (27\%), Fabaceae (12\%), Cyperaceae (3\%), and Rubiaceae (3\%). For Central Depression Fields, the author cites families Poaceae (26\%), Asteraceae (22\%), Fabaceae (9\%), Cyperaceae (7\%), and Rubiaceae (6\%) as the most numerous; while Poaceae (28\%), Asteraceae (15\%), Cyperaceae (13\%), and Solanaceae (4\%) were the richest in the Coastal Fields.

Differences regarding the richest families clearly show that the floristic composition and the structure of the plant community vary significantly according to the physiognomy, probably in response to local variations of soil, relief, and climate. Boldrini et al. (2010) state that the diversity of RS fields is high compared to the richness of grassland formations in other countries. In North America, for example, only 266 species were registered. The authors attribute these differences to soil diversity, which is a result of geological, topographic, rainfall, thermal variability and water availability.

The expeditions performed in the last 14 years in the Pampa fields, especially in the Campos dos Areais region (Fig. 2A-C), have made it possible to see how biodiverse this biome is, especially in terms of vegetation. With each expedition made, with each new place visited, more species become part of the list of native plants of these fields. Unfortunately, more exotic plants are listed too.

To reinforce this high diversity, Bencke (2016) points out that a single square meter of native Pampa field can contain over 50 different species. A study by Caumo (2018) in six permanent preservation areas (PPA) with grassland vegetation, in a forest garden system comprising the species Eucalyptus saligna Sm., in Pantano Grande city, Rio Grande do Sul State, in a region near Serra do Sudeste, recorded the occurrence of 295 species (20 exotic) distributed in 60 families. Among these families, corroborating with other studies, Poaceae (56 species), Asteraceae (54 species), Cyperaceae (19), Fabaceae (17), Rubiaceae (12), Solanaceae (8), Malvaceae (8), and Myrtaceae (6) were the most significant in terms of richness, accounting for $61.35 \%$ of 
the total richness. In addition, herbaceous species were predominant $(72.2 \%$ of the richness), followed by shrub (9.58\%), subshrub (7.87\%), tree (6.16\%), and climbing (5.13\%) species. This confirms what was mentioned in the previous paragraph regarding the predominant habits and the greater representation of Poaceae, both in number of species and in percentage of ground cover.

Figure 2 - Campos dos Areais. A. Grazed field area without arenization, although the soil is exposed; São Francisco de Assis city, near BR 377 (29³5'35.91"S and 5509'11.80'W); B. Sandy field area in Cerro da Esquina, São Francisco de Assis city

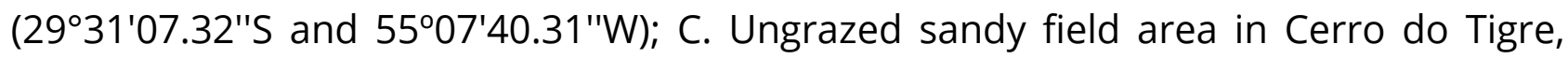

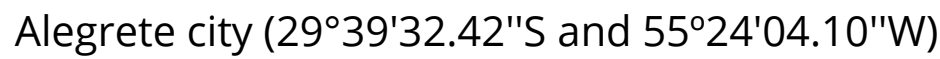

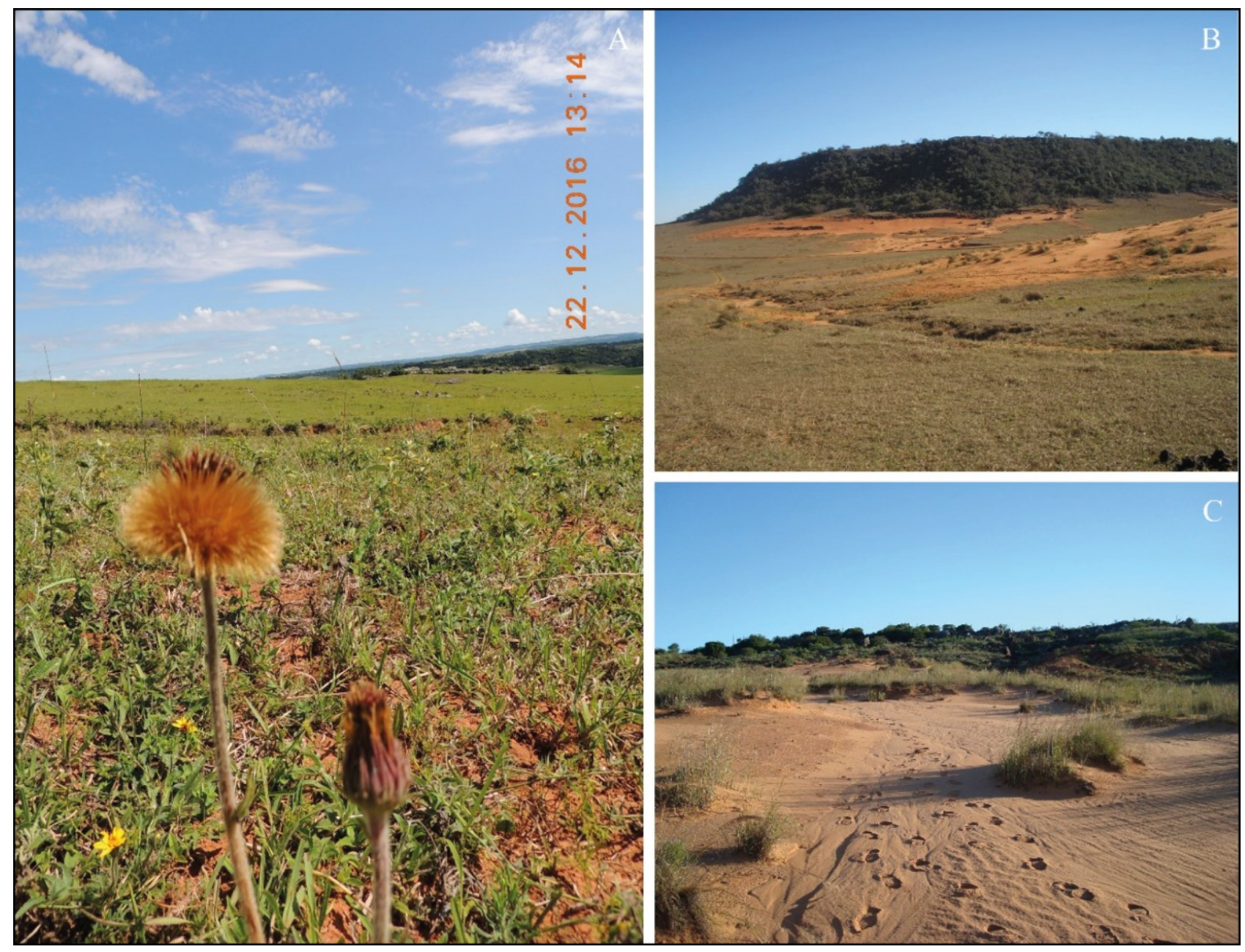


Setubal and Boldrini (2012) evaluated the structure of four grassland communities (rupestrian field, dry field, wet field, and swampy field) in forest-patched mosaics in Serra do Sudeste, RS (Granitic Shield Fields phytophysiognomy). These communities were exposed to periodic burning to eliminate woody species and delay forest expansion. The authors recorded high diversity, with 177 angiosperm taxa distributed in 32 families and 106 genera, including rare species. Asteraceae (39), Poaceae (34), Fabaceae (22), Cyperaceae (12), and Apiaceae (10) were the five most numerous families, slightly different from what was observed by Boldrini (2009) for these fields (see above), since Apiaceae was not listed by the author among the most numerous. Dry and rupestrian fields presented greater similarity to each other, corroborating other studies that showed how environmental characteristics determine differences in the floristic composition and contribute to a greater biodiversity.

Still in Serra do Sudeste, Caporal and Boldrini (2007) evaluated the plant community of a field of approximately four hectares, grazed by sheep and cattle, in Canguçu city, RS. A total of 173 species were sampled, distributed in 115 genera and 34 families, among which Poaceae (58 spp.), Asteraceae (20 spp.), Cyperaceae (14 spp.), and Fabaceae (10 spp.) stood out for the high number of species, similar to that recorded by Boldrini et al. (2009). Despite the high diversity pointed out by the authors in the field studied, Lolium multiflorum L., an introduced hibernal species, showed the highest values of importance in the community.

Freitas et al. (2010) recorded 343 species belonging to 195 genera and 52 botanical families in sandy areas (Campos dos Areais) in the cities of Alegrete, Manoel Viana, and São Francisco de Assis. Among the families, as mentioned by Boldrini (2009) (see above) for fields belonging to the Campos dos Areais phytophysiognomy, those with the highest floristic richness recorded by Freitas et al. (2010) were Asteraceae (22.4\%) (Fig. 3A), Poaceae (17\%), Fabaceae (9\%) (Fig. 3B), Euphorbiaceae (4.4\%), Cyperaceae (3.2\%), Rubiaceae (3.2\%), and Myrtaceae (2.9\%) (Fig. 3C-D). In the same study, the authors recorded two new species for Rio Grande do Sul State (Eragrostis articulata (Schrank) Nees and E. leucosticta Nees ex Döll) and one for Brazil 
(Croton Iorentzii Müll. Arg. ex Griseb.) (Fig. 4). In addition, they highlighted the existence of 20 species of restricted distribution in these fields, of which 7 are exclusive to the sandy soil fields of southwestern RS; and showed the occurrence of 16 endangered and 9 exotic species. This set of information, in addition to showing how diverse the plant community is in these fields, especially in sand-exposed areas, also warned of the need for further research in these areas to increase knowledge about biodiversity and implement actions aimed at its preservation.

Figure 3 - Species recorded in Campos dos Areais. A. Gochnatia cordata Less. (endangered). B. Specimen of Crotalaria tweediana Benth. C. Population of Eugenia arenosa Mattos in a sandy native field in Jacaquá, São Francisco de Assis city. D. Psidium salutare var. sericeum (Cambess.) Landrum. population in a native field area in Cerro do Tigre, Alegrete city

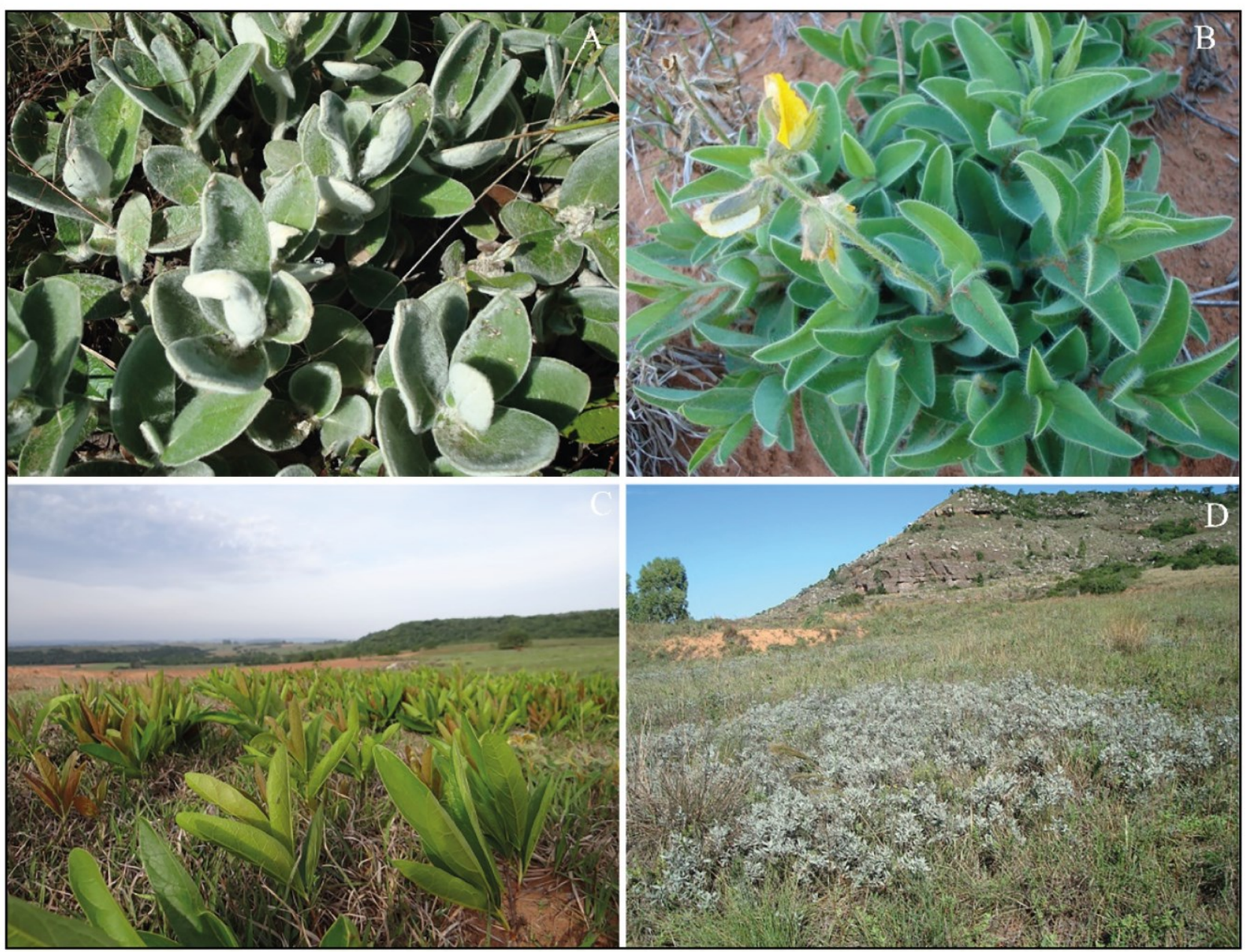


Figure 4 - Croton lorentzii Müll. Arg. ex Griseb. (Euphorbiaceae), an endemic species from Campos dos Areais, in southwestern Rio Grande do Sul State

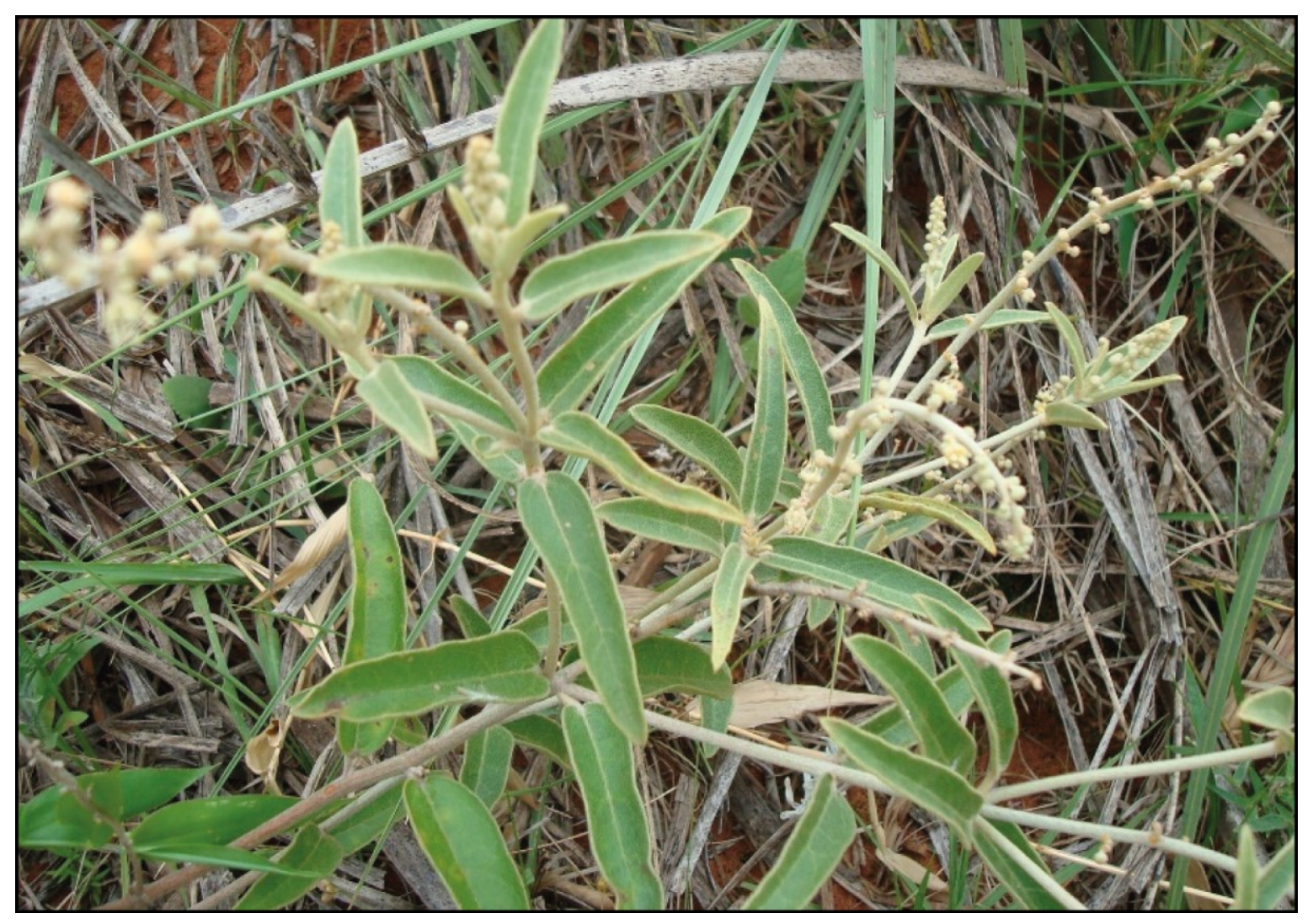

Pinto et al. (2013) evaluated the community structure of a grazed native field in Santana do Livramento city, in the Campanha Gaúcha region classified as Deep Soil Fields, and recorded high diversity indices (229 species and 40 families). Poaceae (62 species; IV = 49.2\%), Asteraceae (28; 15.35\%), Fabaceae (16; 5.46\%), Cyperaceae (12; 1.57\%) were the richest and most important (IV) families. Iridaceae and Plantaginaceae were also among the most numerous, with seven species each. The authors highlight the similarity with other fields in southern Brazil, but emphasize the coexistence of summer and winter species, with a larger amount of winter species, characteristic of basalt-derived Litholic Neosols. The greater representativity of winter species increases the potential of native fields as a forage source for livestock (NABINGER et al., 2009), reinforcing the economic use of these fields. Pinto et al. (2013) also comment on the presence and local dominance of Paspalum indecorum Mez, a rare species cited for the first time in ecological studies conducted in southern Brazil. 
Marchi et al. (2018) characterized the herbaceous and subshrub flora of a threehectare jelly palm ecosystem in Tapes city (RS), classified as Campos do Litoral phytophysiognomy in the Pampa fields region. The authors observed the occurrence of 261 herbaceous and subshrub taxa, 170 genera, and 54 families. As in most studies, Poaceae and Asteraceae showed the highest richness (67 and 49 species, respectively), followed by Fabaceae (20 species), Cyperaceae (10), and Orchidaceae, Iridaceae, and Rubiaceae, with eight species each. Orchidaceae is new among the largest families observed in several studies, highlighting the high diversity that studies in these ecosystems can present. To reinforce the need to preserve the Pampa fields and to increase efforts aimed at their knowledge, their study also recorded a new species of Poaceae, Aristida helleriana M. Marchi, J. Mujica \& R. L. Barbieri.

The various studies approached and performed in different Pampa phytophysiognomies corroborate with Boldrini et al. (2010) when they mention that these fields present a high diversity of species and ecosystems, being in full harmony with the environment. This harmony involves ecological relationships with other organisms and may even serve as a reservoir for species from other groups. To exemplify, a study conducted in the same areas as those studied by Caumo (2018), in Pantano Grande city, recorded four new species of mites, all in grassland plants (TOLDI et al., 2019). The authors also add that many other mite species associated with these plants can be found, as the diversity of Pampa mites is still poorly studied and known. Another very important point to consider is that these plants can still be a reservoir of predatory mites that play a fundamental role in biological control.

\subsection{Adaptive strategies of plants to withstand field environmental conditions}

Pampa fields comprise species that are relict from past climates, which have adaptive structures to extreme climatic conditions, as if they seek to recreate the original environmental conditions (VERDUM, 2016). These structures are common in species that occur throughout the Pampa biome, stressing that the combination of factors such as climate, relief, and soil at various scales has generated "adaptations 
and socializations between plants and animals that, by looking closely, escape any monotony" (VERDUM, 2016, p. 45).

Plants occurring in Campos dos Areais characterize these adaptations very well. This is due to climatic and edaphic heterogeneity in the region: in temperate climates (southern portion of $\mathrm{RS}$ ) there is a higher occurrence of $\mathrm{C}_{3}$ grasses; places with reduced average rainfall and longer periods of summer drought (eastern to western RS), in turn, show a higher presence of drought-adapted plants, including $C_{4}$ and CAM species. In shallow and sandy soils, due to reduced water retention capacity, plants are exposed to stressful water conditions and develop adaptations to prevent water loss, while in more drained soils, species are adapted to these conditions (OVERBECK et al., 2015).

Species survival in the environmental conditions of the Pampa fields (open and hot sites, water scarcity, and low soil fertility) is conditioned to the occurrence of adaptive morphoanatomical and physiological characteristics (AZEVEDO; KAMINSKI, 1995; MARCHIORI, 1995; BOLDRINI, 2009; OVERBECK et al., 2015), which is easily observed in these fields.

In most species, adaptive characteristics are xeromorphic, among which stand out the occurrence of leathery leaves, with varied shapes and positions; dense hairiness; presence of essential oils; and thickened underground organs (Fig. 5A-F) (FREITAS, 2010; BOLDRINI et al., 2010). In the study by Freitas (2010), 89.5\% of the species recorded for Campos dos Areais presented one or more adaptations to stress factors, with leaf adaptations and the development of underground organs being the most frequent strategies. Among leaf characteristics, short or absent petiole and reduced leaf area were the most frequent, although the presence of hairiness was also recurrent. Among underground systems, deep roots and the presence of xylopodium were the most frequent.

The occurrence of developed underground organs is of great importance for species occurring in the Pampa fields. Besides helping to establish the species under different types of soils, they allow rapid vegetation regeneration after fire or grazing, common and indispensable practices for the maintenance of these fields (FIDELIS, 2010; FIDELIS; PIVELLO, 2011; OVERBECK et al., 2015; OVERBECK et al., 2007). In 
addition to serving as a nutritional reserve, these underground organs, especially xylopodiums, have a high sprouting potential, favoring the production and regeneration of shoots after burning episodes, thus ensuring species permanence and survival (FIDELIS, 2008; FIDELIS et al., 2009).

Studies on species of Asteraceae and other angiosperm families occurring specifically in the Campos dos Areais region reveal the presence of epicuticular wax, cuticle and epidermal cells with thickened external periclinal walls, stomata on both leaf surfaces, and supporting tissues (LIESENFELD et al., 2019; VIANA, 2018).

This set of anatomical and morphological characteristics reduces leaf exposure to light, leaf temperature, and water loss without damaging photosynthetic efficiency. Moreover, it also acts in defense against pathogen attack due to the production of a vast amount of chemical compounds (BOEGER; WISNIEWSKI, 2003; RIEDERER; SCHREIBER, 2001; FAHN; CUTLER, 1992; MOTT et al., 1982; LARCHER; BOEGER, 2009; WAGNER et al., 2014). Physiologically, the occurrence of $C_{4}$ metabolism is another adaptive feature to drier environments, as it allows $\mathrm{CO}_{2}$ fixation due to reduced stomatal opening, increasing photosynthetic levels and avoiding water loss through perspiration (SAGE, 2001; SAGE et al., 2011). From the total species recorded by Freitas (2010) for sandy fields, $C_{4}$ and CAM photosynthetic pathways are characteristic of 59 and seven species, respectively. These mechanisms are associated with plants living in habitats under severe environmental conditions. Their presence indicates adaptation to extreme weather conditions, especially associated with intense light and heat and water deficit (LARCHER, 2000).

To exemplify the existence of such adaptations, studies by Viana (2018) and Liesenfeld et al. (2019) with species native to Campos dos Areais showed that different groups of plants, mainly representative of Asteraceae, presented small leathery (14 species) or membranous leaves (12 species) with non-glandular trichomes covering the entire leaf surface, in addition to diverse glandular trichomes, epicuticular wax, cuticle and epidermal cells with thickened external periclinal walls, stomata on both sides, compact mesophyll, secretory channels, phenolic compounds, and mucilage. 
Figure 5 - Adaptive structures observed in species occurring in the Pampa fields of Rio Grande do Sul State. A. Xylopodium of Vernonanthura nudiflora (Less.) H.Rob.; B. Senecio cisplatinus Cabr., with leaves and branches showing a large amount of wax; C. Eugenia arenosa Mattos showing well developed underground system; D. Apical branch of Mandevilla longiflora (Desf.) Pichon, showing woolly hairiness. E. Tuberous root of Manihot hunzikeriana Mart.Crov., with gully-exposed portion corresponding to $98 \mathrm{~cm}$ in length. F. Specimen of Lessingianthus brevifolius (Less.) H.Rob. showing reduced leaves; the species also has deep roots

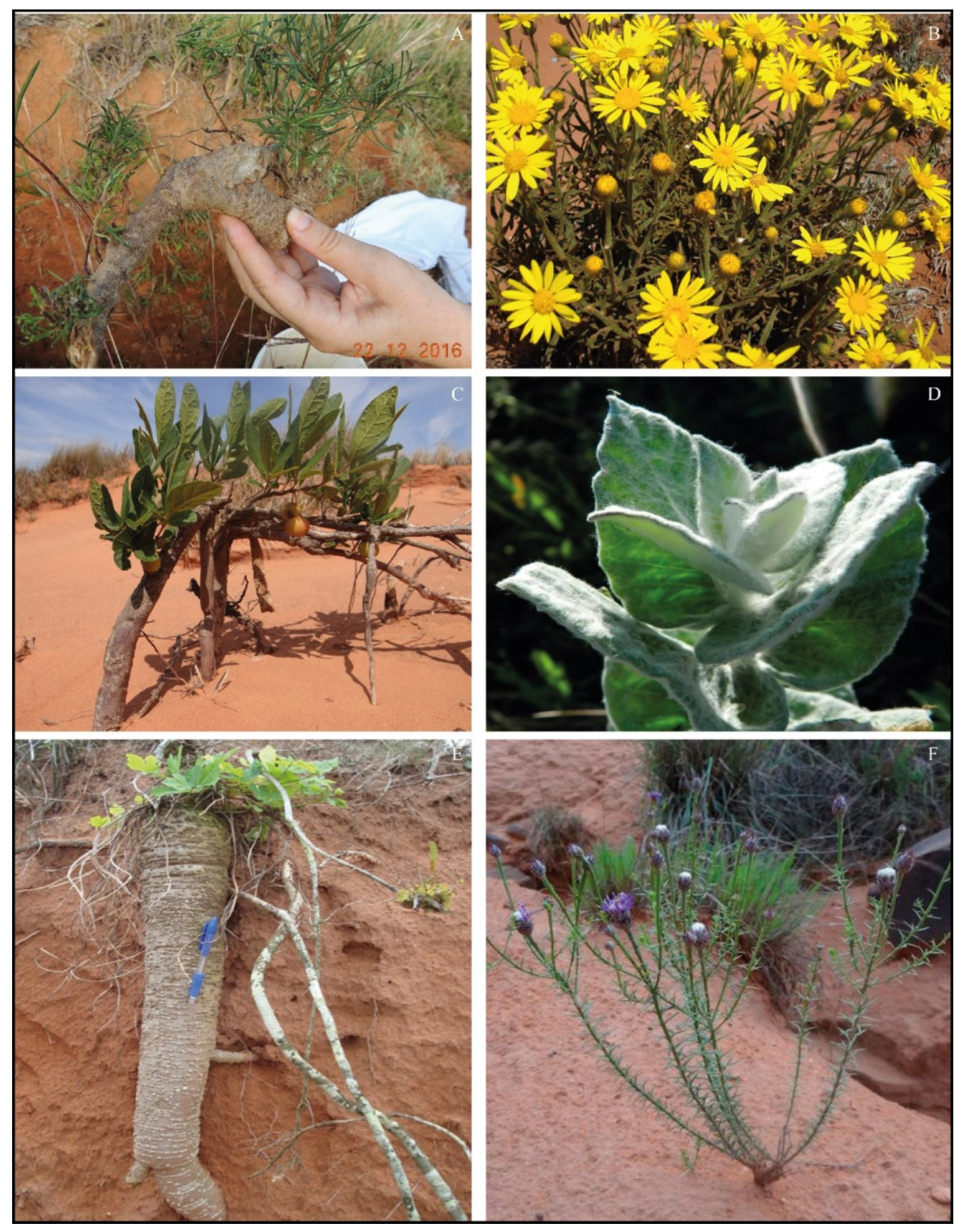


Native to Campos dos Areais, Froelichia tomentosa (Mart.) Moq. (Amaranthaceae) (Fig.6A-B) clearly shows a number of adaptations, including aquifer hypodermis. This species is common in areas with advanced arenization, whose environmental conditions are very extreme. With the function of accumulating water, the aquifer hypodermis favors the survival of plants when under water stress. It also acts as a thermal insulator against excess solar radiation, controlling excessive leaf heating (SILVA; MEDEIROS, 2005; JÁUREGUI et al., 2014).

Figure 6 - Froelichia tomentosa (Mart.) Moq. (Amaranthaceae) A. Habit; B. Leaves detail

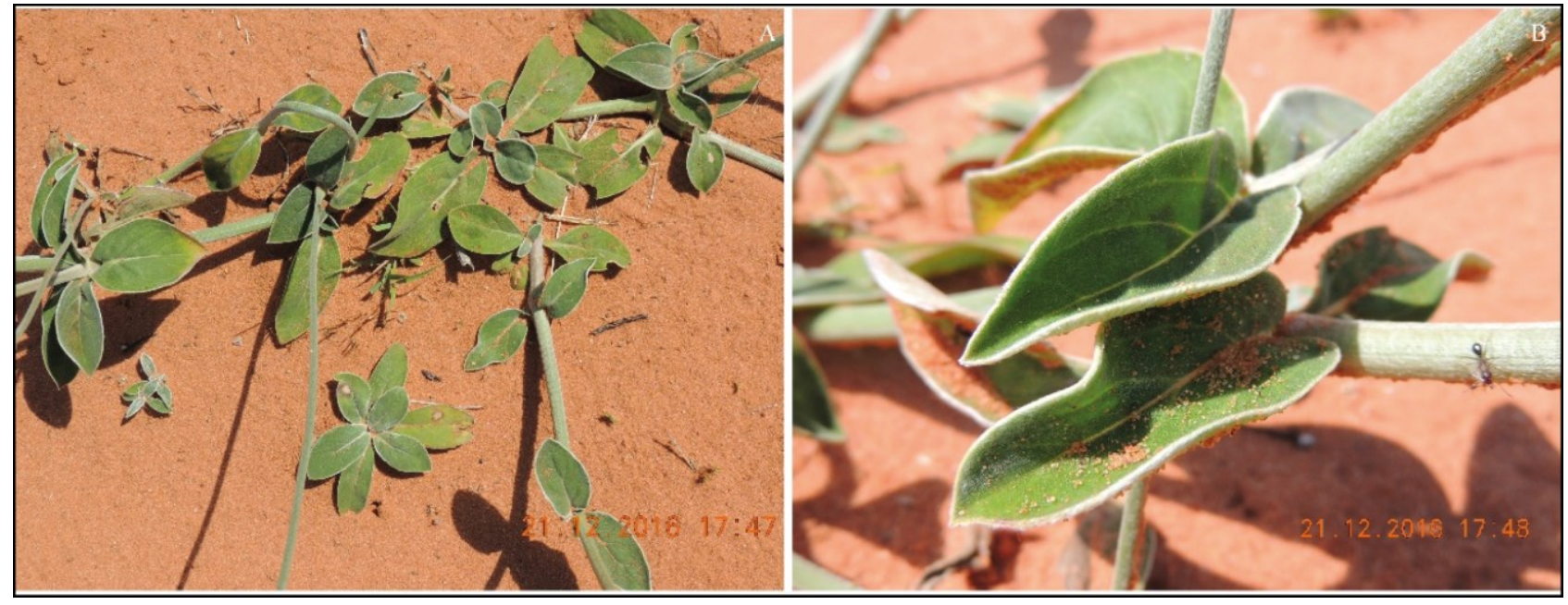

Viana (2018) showed that F. tomentosa, in addition to presenting C4 metabolism, presents opposite crossed phyllotaxis, with thickened leaves at the base of the plant and tomentose indument that contributes to the maintenance of a saturated atmosphere of water vapor around the stomata (ELIAS et al., 2003). This also reduces water loss by evapotranspiration and the intensity of sunlight coming into the mesophyll, preventing increased internal temperature and damage to the photosynthetic apparatus (FANK-DE-CARVALHO et al., 2012).

The adaptive characteristics observed in the species of the Pampa fields, especially in Campos dos Areais, guarantee survival in harsh environments and are also common in species of other similar ecosystems, such as the Cerrado biome and rocky outcrops (ABDALLA et al., 2016; LUSA et al., 2014, 2018; RIZZINI; HERINGER, 1961; FIDELIS; PIVELLO, 2011). These characteristics also contribute to the high 
diversity of plant species recorded in these fields, strongly differentiating it from the others.

\subsection{Current situation of the southernmost fields of Brazil}

All this plant diversity, with its different ecosystems and other associated organisms, is threatened by the transformation of native field areas into agricultural crops and by the introduction of cultivated forages. In addition, intensive use of agrochemicals in crops, overgrazing, and the intense fragmentation of these ecosystems are also of concern. In some cases, not even public roadside areas (sometimes the only refuges of native species) have been spared, as they are often used for agriculture or for brachiaria introduction. The use of fields for forestry purposes and sand exploration in Campos dos Areais are also among the actions that contribute to its degradation. According to Boldrini (2009), all these activities have directly or indirectly deconstructed the grassland scenario in RS, which is taking place along with the loss of the gaucho's culture and figure. This is the scenario created by neglecting the loss of grassland habitats in recent decades due to land conversion to agricultural and forestry uses (BEHLING et al., 2009).

By changing the community, the trophic chain is imbalanced, increasing the populations of certain organisms, especially opportunistic alien species that can become pests (BOLDRINI, 2009). Among the actions that contribute to the reduction of biodiversity, Boldrini (2009) highlights the application of herbicides on native fields to favor the introduction of cultivated forages. In addition to eliminating the local plant community, this practice also promotes soil and water pollution and can contaminate insects that provide environmental services such as pollination.

Despite considering livestock important and essential for the maintenance of native fields in Rio Grande do Sul State, this same author states that cattle grazing leads to overgrazing when improperly practiced, with high animal load, acting in the selection of adapted species and accelerating soil erosion processes.

Although there is no recent data to indicate how much remains of the Pampa fields, each excursion has pointed to an increase of areas transformed into 
agricultural crops, often in total disregard of permanent preservation or legal reserve areas. As a consequence, in addition to local loss of species, fragmentation isolates areas and increases their vulnerability to external influences such as biological invasion (SPEAR et al., 2013).

Kennedy et al. (2002) stated that environments with greater species diversity have greater resistance to invasion by exotic species and suggested that local biodiversity represents an important line of defense against the spread of invasive species. The higher the species richness and the density and agglomeration of a site, the less successful the invaders, regardless of the amount of land found (MACK et al., 2000). Conversely, the conversion of natural fields to other uses favors the establishment of invasive alien species (MEDEIROS et al., 2009). Thus, every degraded environment favors the biological invasion of both fauna and flora, constituting the greatest threat to biodiversity on a global scale (MACK et al., 2000; GLOBAL INVASIVE SPECIES PROGRAM, 2001). Guido and Guadagnin (2015) state that in the case of Campos Sulinos, invasion can be facilitated by improper management of the fields, including overgrazing and land use changes. This is especially critical with the abandonment of intensive land use areas and with the recurrent introduction of species recognized as invasive. Mack et al. (2000) also claim that invasive species may interfere with the biota, further changing species functions in communities, evolutionary processes, and species abundance, leading them to extinction.

Given the many disturbances in these fields, it can be inferred that invasive species present a major threat to all their biological diversity. This disturbance has often been observed in the remaining native field areas. Freitas et al. (2010) recorded nine exotic species, two of which are considered invasive to RS (Eragrostis plana Nees and Melinis repens (Willd.) Zizka) and classified as category 1 according to SEMA Ordinance No. 79 of October 31, 2013 (SEMA, 2013). This Ordinance prohibits the transport, creation, release/translocation, cultivation, propagation, trade, acquisition, or intentional donation of species included in category 1 , due to their high invasive potential. Caumo (2018) recorded 20 exotic species, including E. plana. Marchi et al. 
(2018) reported the presence of E. plana and Urochloa decumbens (Stapf) R.D.Webster, the latter also included in the list of RS invaders (SEMA, 2013).

Eragrostis plana, popularly known as annoni grass and originating in Africa, has been causing great damage to native fields. It is not consumed by cattle due to its anatomical characteristics and high levels of lignin (FAVARETTO et al., 2015). Furthermore, it adapts quickly to various environments and it is easily established in the field, and has been occupying large areas where it competes with the other species (MARCHI et al., 2018). Medeiros et al. (2009) state that the exclusion of annoni grass during cattle grazing has contributed to its expansion. This is because animals choose native plants with higher nutritional value, favoring the growth and reproduction of the invader. Given this, Medeiros et al. (2009) state that the occurrence of $E$. plana has determined a reduction in the frequency and abundance of native species, and losses in animal productivity.

\subsection{Why preserve the southernmost fields of Brazil?}

The main reason for the preservation of the fields is their biodiversity, characterized by their high richness, being distinct from all other grassland ecosystems on the planet and constituting an extremely valuable genetic resource. Another reason is its historical and cultural importance, since destroying or degrading the fields of Rio Grande do Sul State means threatening the culture of the gaucho people. Furthermore, these fields should be preserved for the scenic beauty of their different ecosystems that favors tourism (BEHLING et al., 2009; PILLAR et al., 2015; BENCKE, 2016).

All this diversity ensures the provision of ecosystem services, with their maintenance constituting benefits for human populations (PILLAR et al., 2015). The same authors state that among these services are water regulation, clean water supply, livestock forage production, pollinator maintenance, mitigation of global climate change as a result of carbon storage, and food supply to other organisms, contributing to the maintenance of the food chain and ecological balance. In addition to the above, these fields store predators of agricultural pests. This is the case, for 
example, with predatory mites (DEMITE et al., 2015). These animals migrate to neighboring farming systems where they feed on phytophagous individuals, promoting population control. During the off-season, these predators find food and shelter in native ecosystems (DEMITE et al., 2013; ROCHA et al., 2015; TOLDI et al., 2019). Several other organisms live in native environments and can act in biological control, knowledge of which can lead to the development of pest control products and the consequent reduction in the use of synthetic insecticides and fungicides.

Besides biological control, other potentials reinforce that this diversity is an important genetic resource for economic and sustainable exploitation, ensuring preservation and financial return. According to Behling et al. (2009), Pillar et al. (2015), and Bencke (2016), native species from RS fields present forage, ornamental, food, cosmetic, medicinal, insecticidal, and allelopathic potential, in which active compounds can be used for the development of new products. However, little is known about these potentials. It is known, for example, that many plants are medicinal or can eliminate certain insects, but their bioactive compounds and respective activities are not known, showing the need for investments in bioprospecting research on these species. This lack of information reinforces the importance of preserving these grassland ecosystems.

The great diversity of species with forage potential in the Pampa fields, coexisting with summer and hibernal grasses, makes them particularly suitable for livestock. When properly managed, they provide a high-quality and varied natural diet, producing meat with highly appreciated and differentiated sensory and nutritional characteristics (BEHLING et al., 2009). Among the species with forage potential are Paspalum notatum Flüggé (bahia grass), Paspalum dilatatum Poir (dallis grass), and Axonopus affinis Chase (carpet grass). To these can be added Fabaceae species that, in addition to having forage potential, promote natural fertilization of fields and can be used to recover degraded areas in regions where their occurrence is natural (BENCKE, 2016), as is the case of Lupinus albescens Hook. \& Arn. (Fig. 7A-D) (ROVEDDER et al., 2009). 
Figure 7 - A-B. Population of Lupinus albescens Hook. \& Arn. in an ungrazed native field area in Cerro do Tigre, Alegrete city; C. A large specimen; D. Inflorescence detail

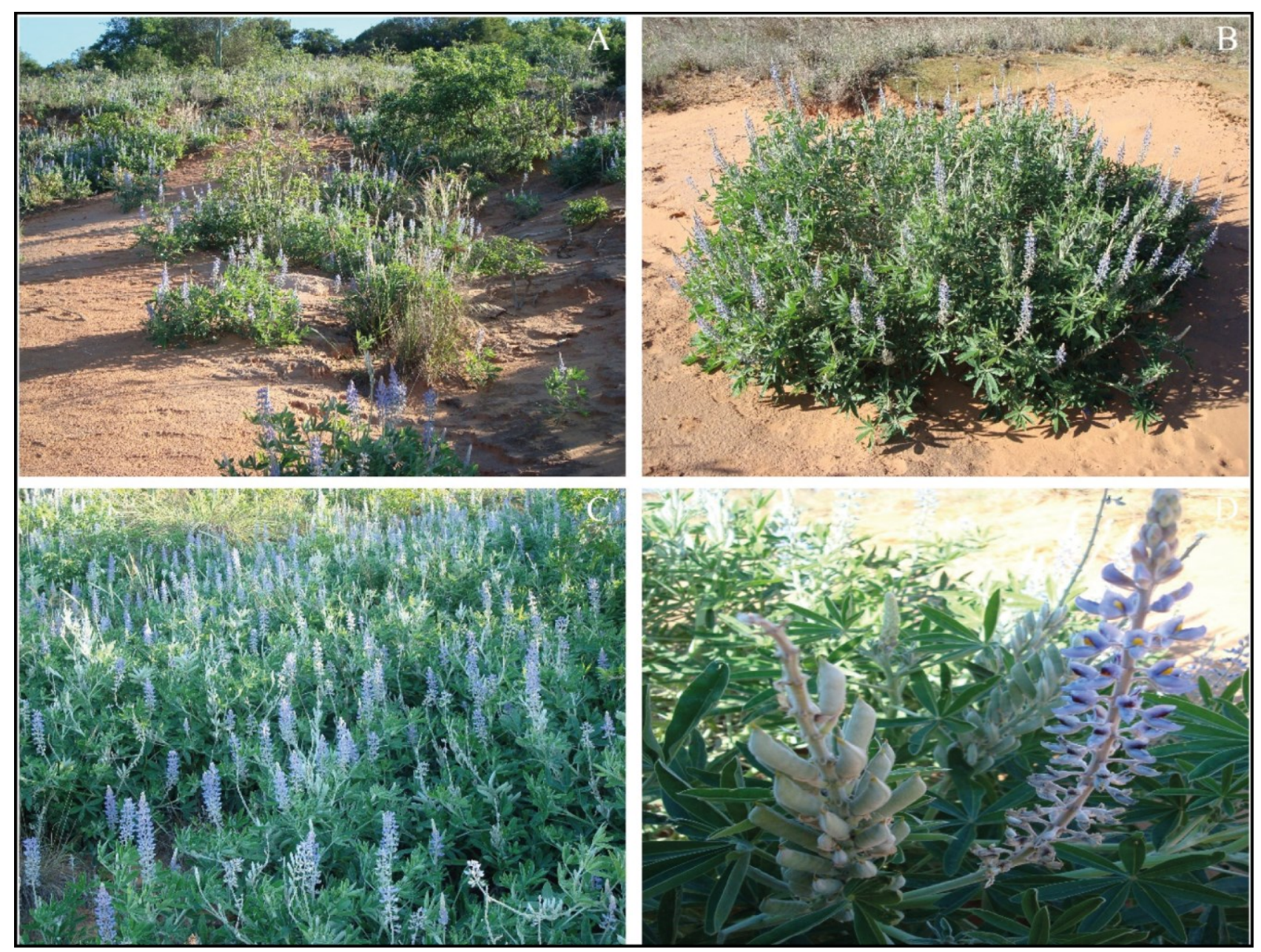

Furthermore, species of the genus Butia can be widely explored. According to Marchi et al. (2018), B. odorata (Barb.Rodr.) Noblick has multiple uses, with potential for food, ornamental, melliferous, and handicraft applications. These same uses can be cited for all other species of the genus due to the similarity in their structures, as is the case of B. lallemantii Deble \& Marchiori (Fig. 8A-C), endemic to Campos dos Areais and widely occurring in preserved portions of native field.

Endemic to the Pampa fields, Hesperozygis ringens (Benth.) Epling (Lamiaceae) (Fig. 9A-B) is another species with different possibilities of use. Ribeiro et al. (2010) showed that its essential oil has high larvicidal potential and interferes with the production of Rhipicephalus microplus eggs. Silva et al. (2013) recommended the use of its oil as an anesthetic in fish capture and handling. Moreover, Von Poser et al. (1996) showed that 
the alcoholic extract of its leaves and the essential oil have antigerminative properties, suggesting the possibility of its use for the development of natural herbicides. According to Rosa et al. (2007), the development of bioherbicides may be favored when the active principle of allelopathic substances present in plants is detected. This is the case of $\mathrm{H}$. ringens, whose oil has high concentrations of pulegone (79.2\%), with antimicrobial, fungicidal, insecticidal, and allelopathic action (VON POSER et al., 1996).

Figure 8 - A. Specimen of Butia lallemantii Deble \& Marchiori photographed at Cerro do Tigre, Alegrete city; B. Species population in a sandy field in São Francisco de Assis city, near BR 377; C. Species population in a native field area with lower incidence of sanding in Taquari, São Francisco de Assis city

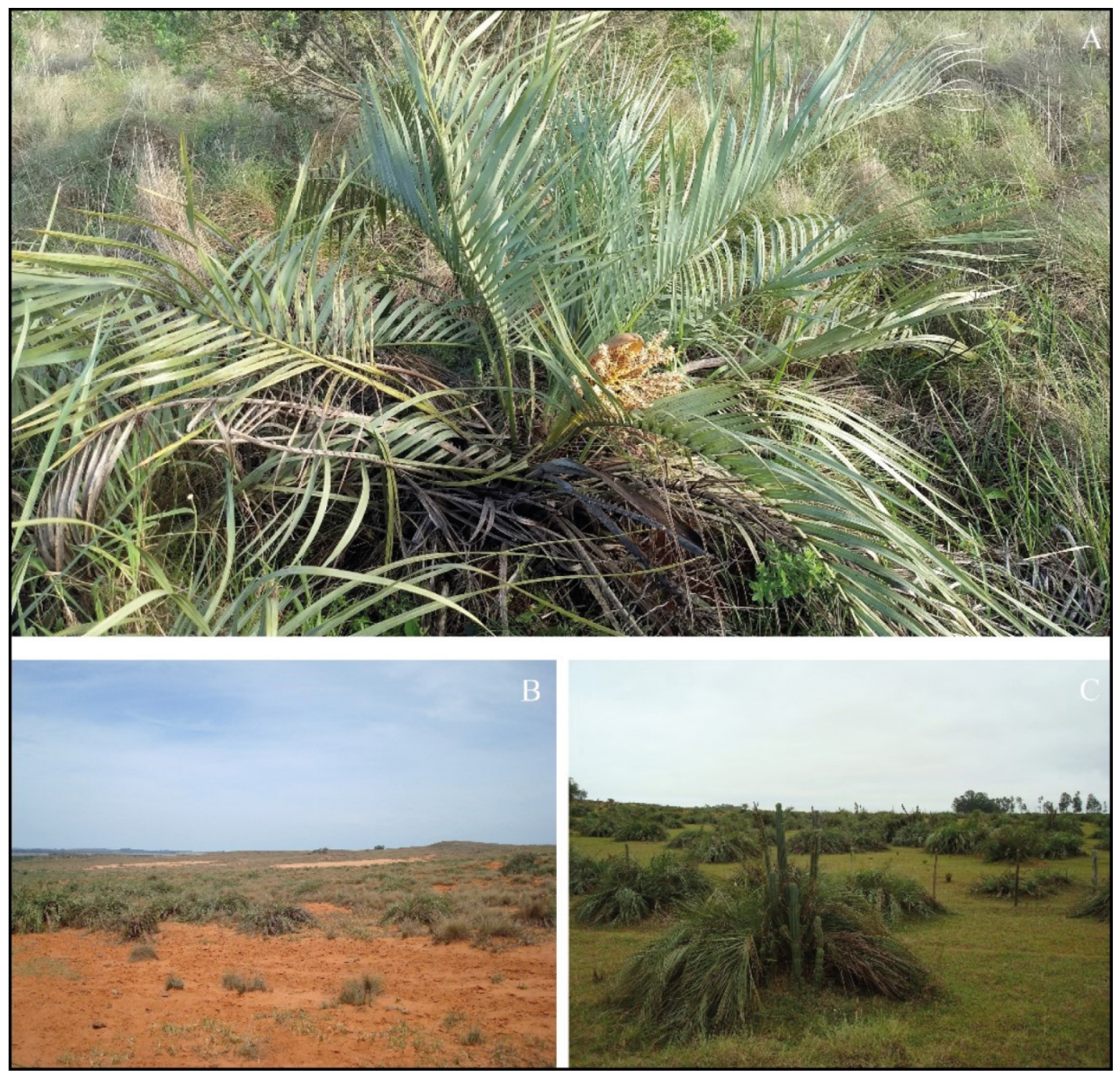


Figure 9 - A. Hesperozygis ringens (Benth.) Epling (Lamiaceae) population sandy fields; B. Inflorescence detail

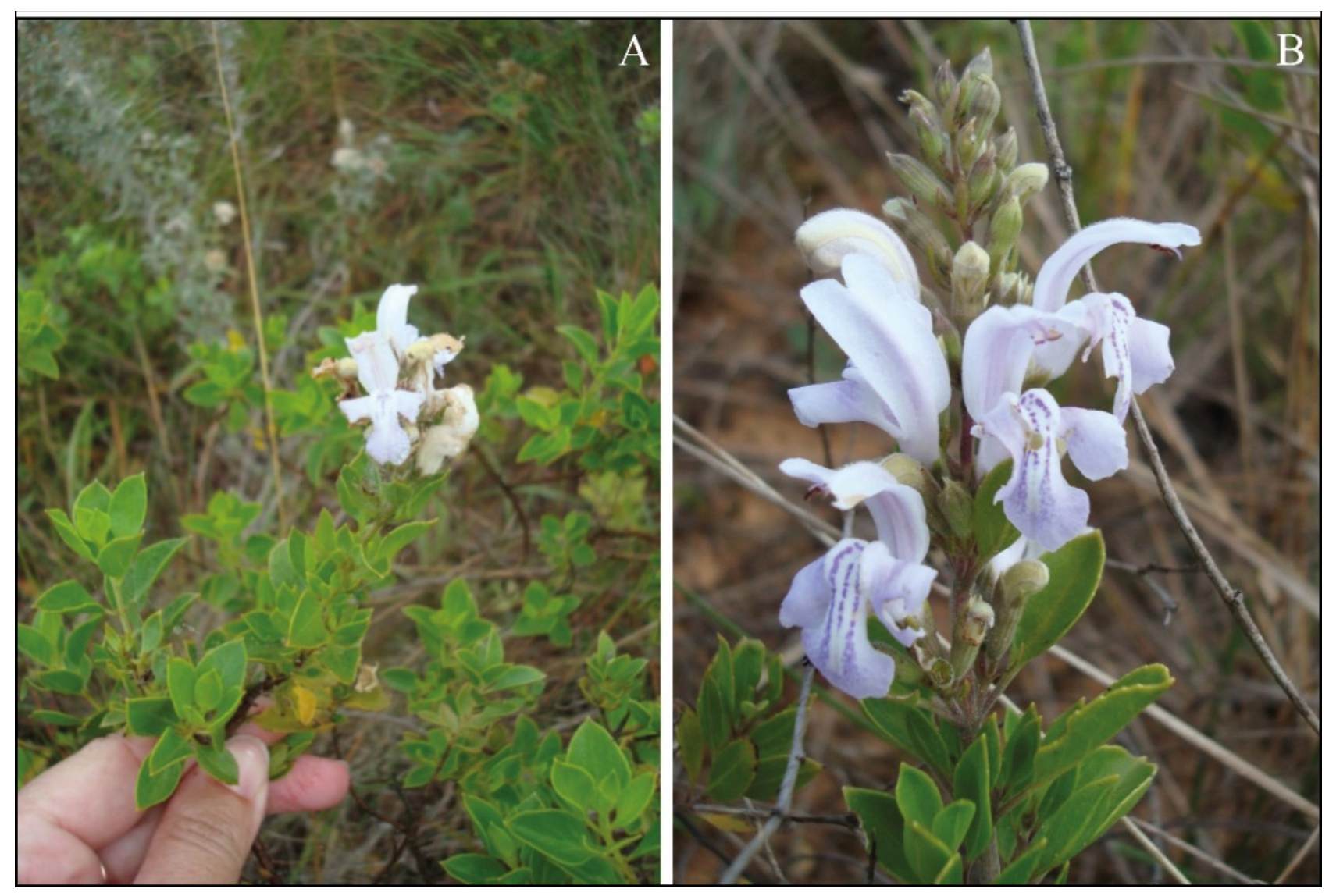

To highlight other potentials of species from the southernmost fields of RS, it has recently been found that the essential oil of species Campomanesia aurea O.Berg (Myrtaceae) (Fig. 10A), native to the rupestrian fields of RS, has efficient antimicrobial activity against Listeria monocytogenes ATCC 19114 and Staphylococcus aureus ATC 25923. It can also act as a biofilm inhibitor for L. monocytogenes, S. aureus, and Salmonella enteritidis ATCC 13076, which are pathogenic microorganisms that are difficult to eliminate, being found in foods (KUHN et al., 2019). 
Figure 10 - A. Campomanesia aurea O.Berg (Myrtaceae); B. Eugenia pitanga (O.Berg) Nied.; C. Psidium salutare var. sericeum (Cambess.) Landrum.; D. Eugenia anomala D.Legrand with green fruits

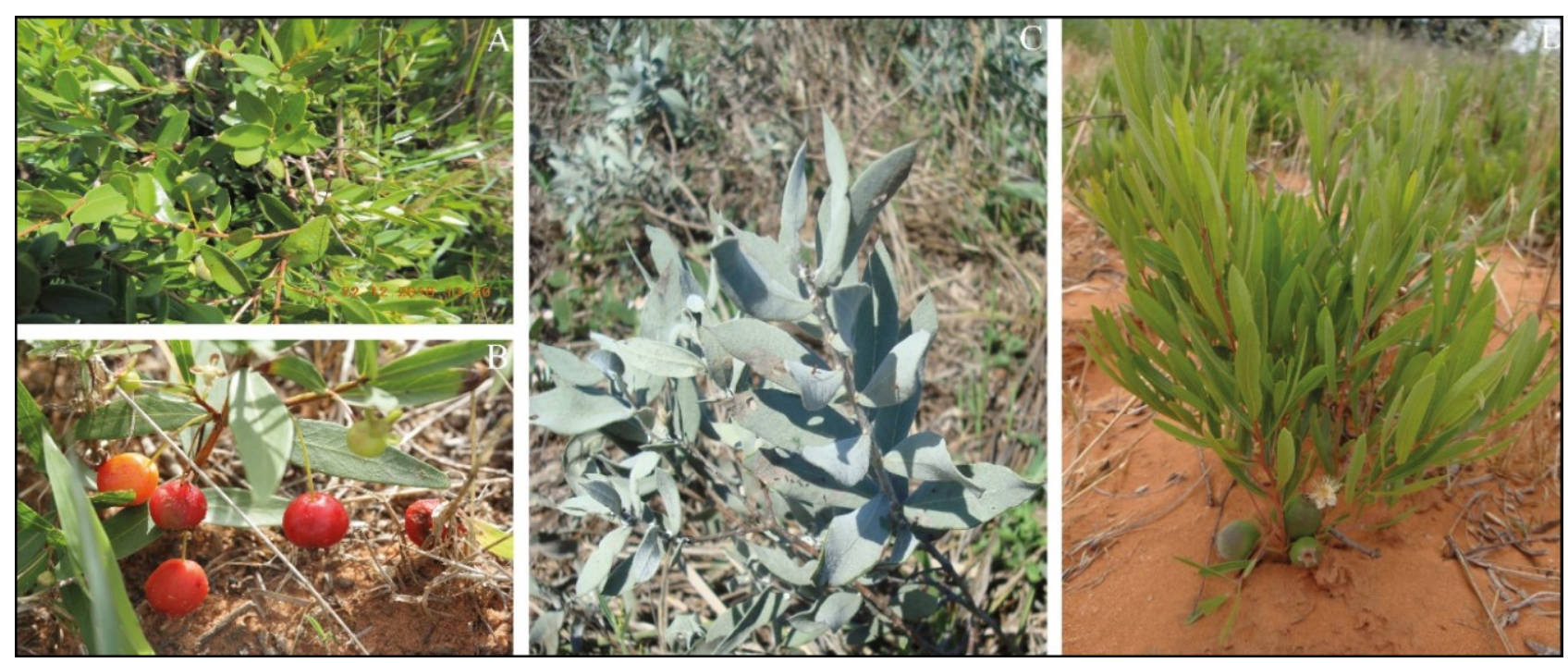

Studies with aqueous and ethanolic extracts of Eugenia arenosa Mattos (Fig. 5C), E. pitanga (O.Berg) Nied. (Fig. 10B), and Psidium salutare (Kunth) O.Berg (Fig. 10C) showed in vitro leishmanicidal activity against promastigote forms of Leishmania amazonenses (KAUFFMANN et al., 2017a). The essential oil of E. pitanga also showed action against $L$. amazonenses, with an inhibitory potential similar to that of the standard drug pentamidine (KAUFFMANN et al., 2017b). Another study with extracts of Eugenia anomala D.Legrand. (Fig. 10D), E. arenosa, and E. pitanga showed in vitro antimicrobial and antibiofilm activity against S. aureus and Pseudomonas aeruginosa (KAUFFMANN et al., 2017c).

The results of the potential investigated for these species, all native to the sandy fields of southwestern Rio Grande do Sul State, are promising when considered that their extracts and essential oils are complex compounds and may exhibit more pronounced activities if purified and tested for their isolated components, becoming a possible source for drug development (KAUFFMANN et al., 2017c). The few bioprospecting studies on species from these sites suggest that much remains to be discovered and that actions need to be taken to inhibit field destruction. 


\section{CONCLUSIONS}

The southernmost fields of Brazil have high plant diversity as a result of the different environmental, geomorphological, and edaphic conditions existing throughout their extension, constituting a unique genetic heritage. Research conducted with native species indicates that they have potential for different uses and can be explored sustainably, ensuring the economic viability of rural properties. Notwithstanding, actions must be taken to prevent their destruction and promote their preservation. Further studies should be conducted to better characterize this extremely diverse and yet neglected environment.

Fields have never been treated as priority areas for conservation in Brazil. According to Boldrini (2009, p. 76), "it is our commitment, as a civilized society, to respect life and to maintain a healthy environment for the current and future generations, acting in a sustainable manner, minimizing environmental impacts, and respecting the conscious livestock vocation of the grass/and ecosystem".

\section{ACKNOWLEDGEMENT}

To Professor Dr. Roberto Verdum (UFRGS) who introduced me to the sanded fields of southwestern RS, and to Dra. Ilsi lob Boldrini (UFRGS) for all the teaching about the RS fields. To all the people who, over the years, accompanied me and helped in the field activities in order to know the plant communities of the Pampa Gaúcho fields.

\section{REFERENCES}

ABDALLA DF, MORAES MG, REZENDE MH, HAYASHI AH, CARVALHO MAM. Morphoanatomy and fructans in the underground system of Apopyros warmingii and Ichthyothere terminalis (Asteraceae) from the cerrado rupestre. J. Torrey Bot. Soc. 2016;143(1):69-86. 
AZEVEDO AC, KAMINSKI J. Considerações sobre os solos dos campos de areia no Rio Grande do Sul. Ciência \& Ambiente. 1995; 11:65-70.

BAUERMANN SG, MACEDO RB, BEHLING H, PILLAR VP, NEVES PCP. Dinâmicas vegetacionais, climáticas e do fogo com base em palinologia e análise multivariada no quaternário tardio do sul do Brasil. Rev. bras. paleontol. 2008;11(2):87-96.

BEHLING H, JESKE-PIERUSCHKA V, SCHÜLER L, PILLAR VP. Dinâmica dos campos no sul do Brasil durante o Quaternário Tardio. In: Pillar VD, Müller SC, Castilhos ZMS, Jacques AVA, editors. Campos Sulinos - Conservação e uso sustentável da Biodiversidade. Brasília: MMA; 2009. p. 13-25.

BEHLING H, PILLAR V, BAUERMANN SG. Late Quaternary Araucaria forest, grassland (campos), fire and climate dynamics, inferred from a high-resolution pollen record of Cambará do Sul in southern Brazil. Palaeo. 2004; 203:277-297.

BEHLING H, PILLAR VD, BAUERMANN SG. Late Quaternary grassland (Campos), gallery forest, fire and climate dynamics studied by pollen, charcoal and multivariate analysis of the São Francisco de Assis core in western Rio Grande do Sul (southern Brazil). Review of Paleobotany and Palynology. 2005;133(3-4):235-248.

BENCKE GA. Biodiversidade. In: Chomenco L, Bencke GA, organizers. Nosso Pampa desconhecido. Porto Alegre: Fundação Zoobotânica do Rio Grande do Sul; 2016. p. 6375.

BILENCA DN, MIÑARRO FO. Identificación de áreas valiosas de pastizal en las pampas y campos de Argentina, Uruguay y sur de Brasil. Buenos Aires: Fundación Vida Silvestre Argentina; 2004.

BOEGER MRT, WISNIEWSKI C. Comparação da morfologia foliar de espécies arbóreas de três estádios sucessionais distintos de floresta ombrófila densa (Floresta Atlântica) no Sul do Brasil. Rev. Bras. Bot. 2003;26(1):61-72.

BOLDRINI II. A flora dos Campos do Rio Grande do Sul. In: Pillar VD, Müller SC, Castilhos ZMS, Jacques AVA, editors. Campos Sulinos - Conservação e uso sustentável da Biodiversidade. Brasília: MMA; 2009. p. 63-77.

BOLDRINI II, FERREIRA PMA, ANDRADE BO, SCHNEIDER AA, SETUBAL RR, TREVISAN R et al. Bioma Pampa: diversidade florística e fisionômica. Porto Alegre: Pallotti; 2010.

BOLDRINI II, OVERBECK GE, TREVISAN R. Biodiversidade de Plantas. In: Pillar VP, Lange O, editors. Os Campos do Sul. Porto Alegre: Rede Campos Sulinos - UFRGS; 2015. p. 51-59.

CABRERA AL, WILLINK A. Biogeografia da América Latina. 2 st ed. Washington: OEA; 1980. 
CAPORAL FJM, BOLDRINI II. Florística e fitossociologia de um campo manejado na Serra do Sudeste, Rio Grande do Sul. R. bras. Bioci. 2007; 5(2-3):37-44.

CAUMO M. Estudo de comunidades vegetais em Áreas de Preservação Permanente associadas à silvicultura e à pecuária no bioma Pampa, Rio Grande do Sul [dissertation]. Porto Alegre: Faculdade de Agronomia/UFRGS; 2018. p. 122.

DEMITE PR, FERES RJF, LOFEGO AC. Influence of agricultural environment on the plant mite community in forest fragments. Brazilian Journal of Biology. 2015; 75(2):396-404.

DEMITE, PR.; LOFEGO, Antonio C.; FERES, Reinaldo JF. Mite (Acari; Arachnida) diversity of two native plants in fragments of a semideciduous seasonal forest in Brazil. Systematics and Biodiversity. 2013; 11(2):141-148.

ELIAS SR, ASSIS RM, STACCIARINI-SERAPHIN E, REZENDE MH. Leaf anatomy in young plants of Solanum lycocarpum A. St.-Hil. (Solanaceae). Brazilian Journal of Botany. 2003; 26:169-174.

FAVARETTO A, CHINI SO, CHEFFER-BASSO SM, SOBOTTKA AM, BERTOL CD, PEREZ NB. Pattern of allelochemical distribution in leaves and roots of tough lovegrass (Eragrostis plana Nees). Aust. J. Crop Sci. 2015;9(11):1119-1125.

FAHN A, CUTLER DF. Xerophytes. Berlin: Gebruder Borntraeger; 1992.

FANK-DE-CARVALHO SM, BÁO SN, MARCHIORETTO MS. Amaranthaceae as a bioindicator of neotropical savannah diversity. In: Gbolagade Akeem Lameed, editor. Biodiversity Enrichment in a Diverse World. Croatia: InTech: 2012. p. 235-256.

FIDELIS A. Fire in subtropical grasslands in Southern Brazil: effects on plant strategies and vegetation dynamics. [Dissertation]. Munich: Technische Universität München; 2008. p. 151.

FIDELIS A. South Brazilian Campos grasslands: biodiversity, conservation and the role of disturbance. In: Runas J, Dahlgren T, editors. Grassland biodiversity: habitat types, ecological processes and environmental impacts. New York: Nova Science Publisher; 2010. p. 223-239.

FIDELIS A, APPEZZATO-DA-GLÓRIA B, PFADENHAUER J. A importância da biomassa e das estruturas subterrâneas nos Campos Sulinos. In: Pillar VD, Müller SC, Castilhos ZMS, Jacques AVA, editors. Campos sulinos - conservação e uso sustentável da biodiversidade. Brasília: MMA; 2009. p. 85-97.

FIDELIS A, PIVELLO VR. Deve-se Usar o Fogo como Instrumento de Manejo no Cerrado e Campos Sulinos? Biodiversidade Brasileira. 2011; 2:12-25. 
FREITAS EM, BOLDRINI II, MULLER SC, VERDUM, R. 2009. Florística e fitossociologia da vegetação de um campo sujeito à arenização no sudoeste do Rio Grande do Sul, Brasil. Acta Botânica Brasílica. 2009;8(1):112-130.

FREITAS EM. Campos de solos arenosos do sudoeste do Rio Grande do Sul: aspectos florísticos e adaptativos [thesis]. Porto Alegre: Instituto de Biociências/UFRGS; 2010. p. 171.

FREITAS EM, TREVISAN R, SCHNEIDER AA, BOLDRINI II. Floristic diversity in areas of sandy soil grasslands in Southwestern Rio Grande do Sul, Brazil. Brazilian Journal of Biosciences. 2010;8(1):112-130.

GLOBAL INVASIVE SPECIES PROGRAMME. Global strategy on invasive alien species. IUCN. 2001. p. 50.

GUIDO A, GUADAGNIN DL. Espécies exóticas invasoras. In: Pillar VP, Lange O, editors. Os Campos do Sul. Porto Alegre: Rede Campos Sulinos - UFRGS; 2015. p. 133140.

HASENACK H, CORDEIRO JLP, COSTA BSC. Cobertura vegetal atual do Rio Grande do Sul. In: Dall'agnol M, Nabinger C, Sant'Anna DM, Santos RJ, editors. Sustentabilidade produtiva no Bioma Pampa. II Simpósio de Forrageiras e Produção Animal. Porto Alegre: Departamento de Forrageiras e Agrometeorologia - UFRGS; 2007. p. 15-22.

HASENACK H, WEBER E, BOLDRINI II, TREVISAN R. Mapa de sistemas ecológicos da ecorregião das savanas uruguaias em escala 1:500.000 ou superior e relatório técnico descrevendo insumos utilizados e metodologia de elaboração do mapa e metodologia de elaboração do mapa de sistemas ecológicos. Relatório Técnico: The Nature Conservancy. 2010.

INSTITUTO BRASILEIRO GEOGRAFIA e ESTATÍSTICA - IBGE. Mapa da vegetação do Brasil e Mapa de biomas do Brasil. Brasília. 2004. Disponível em https://www.ibge.gov.br/geociencias/informacoes-ambientais/estudos-

ambientais/15842-biomas.html?=\&t=acesso-ao-produto. Acesso em 1 de agosto de 2019.

KAUFFMANN C, PACHECO LA, BUHL B, SCHEIBEL T, FREITAS EM, HOEHNE L et al. Avaliação da atividade leishmanicida in vitro de espécies da família Myrtaceae, nativas do sul do Brasil. Revista Destaques Acadêmicos. 2017a;9(3):246-258.

KAUFFMANN C, ETHUR EM, AROSSI K, HOEHNE L, FREITAS EM, MACHADO GMC et al. Chemical Composition and Evaluation Preliminary of Antileishmanial Activity in vitro of Essential Oil from Leaves of Eugenia pitanga, A Native Species of Southern of Brazil. J Essent Oil Bear PI. 2017b;20(2):559-569. 
KAUFFMANN C, SOARES APV, AROSSI K, PACHECO LA, BUHL B, FREITAS EM et al. Potencial antimicrobiano e antibiofilme in vitro de espécies do gênero Eugenia, Myrtaceae, nativas do sul do Brasil. Revista Caderno Pedagógico. 2017c;14(2):110-127.

KENNEDY TA, NAEEM S, HOWE KM, KNOPS JMH, TILMAN D, REICH P. Biodiversity as a barrier to ecological invasion. Nature. 2002; 417:636-638.

KUHN D, ZIEM R, SHEIBEL T, BUHL B, VETTORELLO G, PACHECO LA et al. Antibiofilm activity of the essential oil of Campomanesia aurea O. Berg against microorganisms causing food borne diseases. LWT - Food Sci. Technol. 2019; 108:247-252.

JÁUREGUI D, CASTRO M, RUIZ-ZAPATA T, LAPP M. Anatomy of the vegetative organs of two species of Atriplex (Chenopodiaceae) from Venezuela. Rev. biol. trop. 2014;62(4):1625-1636.

LARCHER L, BOEGER MRT. Arquitetura foliar de Odontonema strictum (Nees) O. Kuntze (Acanthaceae) em duas condições de luminosidade. Hoehnea. 2009; 36:321327.

LARCHER W. Ecofisiologia Vegetal. São Carlos: Rima Artes e Textos; 2000.

LEONHARDT A, LORSCHEITTER ML. The last 25,000 years in the Eastern Plateau of Southern Brazil according to Alpes de São Francisco record. Journal of South American Earth Sciences. 2010; 29:454-463.

LIESENFELD V, GENTZ P, FREITAS EM, MARTINS. Leaf morphology and anatomy of Asteraceae of the Pampas biome (sand-fields). Flora. 2019; 258:151418.

LINDMAN CAM. A vegetação do Rio Grande do Sul. Porto Alegre: Universal; 1906.

LUSA MG, APPEZZATO-DA-GLÓRIA B, LOEUILLE B, BARTOLI G, CICCARELLI D. Functional groups in Lychnophorinae (Asteraceae: Vernonieae) based on morphological and anatomical traits. Aust. J. Bot. 2014; 62:150-163.

LUSA MG, LOEUILLE BFP, CICCARELLI D, APPEZZATO-DA-GLÓRIA B. Evolution of stem and leaf structural diversity: a case study in Lychnophorinae (Asteraceae). Bot. Rev. 2018; 84:203-241.

MACK RN, SIMBERLOFF D, LONSDALE WM, EVANS $H$, CLOUT $M$, BAZZAZ FA. Biological Invasions: causes, epidemiology, global consequences and control. Ecol. Appl. 2000; 10:689-710.

MARCHI MM, BARBIERI RL, SALLES JM, COSTA FA. Herbaceous and subshrubby flora associated with palm grove ecosystem in the Pampas Biome. Rodriguésia. 2018;69(2):553-560.

MARCHIORI JNC. Vegetação e areais no sudoeste rio-grandense. Ciência \& Ambiente. 1995; 11:53-64. 
MEDEIROS RB, SAIBRO JC, FOCHT T. Invasão de capim-annoni (Eragrostis plana Nees) no bioma Pampa do Rio Grande do Sul. In: Pillar VD, Müller SC, Castilhos ZMS, Jacques AVA, editors. Campos Sulinos - Conservação e uso sustentável da Biodiversidade. Brasília: MMA; 2009. p. 317-331.

MOTT KA, GIBSON AC, O'LEARY JW. The adaptive significance of amphistomatic leaves. Plant Cell Environ. 1982; 5:455-460.

NABINGER C, FERREIRA ET, FREITAS AK, CARVALHO PCF, SANT'ANNA DM. Produção animal com base no campo nativo: aplicações de resultados de pesquisa. In: Pillar VD, Müller SC, Castilhos ZMS, Jacques AVA, editors. Campos Sulinos - Conservação e uso sustentável da Biodiversidade. Brasília: MMA; 2009. p. 175-198.

OVERBECK GE, BOLDRINI II, DO CARMO MRB, GARCIA EN, MORO RS, PINTO CE, TRESVISAN R, ZANNIN A. Fisionomia dos Campos. In: Pillar VP, Lange O, editors. Os Campos do Sul. Porto Alegre: Rede Campos Sulinos - UFGRS; 2015. p. 31-41.

OVERBECK G, MULLER S, FIDELIS A, PFADENHAUER J, PILLAR V, BLANCO C et al. Brazil's neglected biome: The South Brazilian Campos. Perspectives in Plant Ecology, Evolution and Systematics. 2007;9(2):101-116.

OVERBECK GE, MÜLLER SC, FIDELIS A, PFADENHAUER J, PILLAR VDP, BLANCO CC et al. Os Campos Sulinos: um bioma negligenciado. In: Pillar VDP, Müller SC, Castilhos ZMC, Jacques AVA, editors. Campos Sulinos - conservação e uso sustentável da biodiversidade. Brasília: MMA; 2009. p. 26-41.

OVERBECK GE, PFADENHAUER J. Adaptive strategies in burned subtropical grassland in southern Brazil. Flora. 2007;202(1):27-49.

OVERBECK GE, SCASTA JD, FURQUIM FF, BOLDRINI II, WEIR JR. The South Brazilian grasslands - A South American tallgrass prairie? Parallels and implications of fire dependency. Pecon. 2018; 16:24-30.

PILLAR VP. Dinâmica da expansão florestal em mosaicos de floresta e campos no sul do Brasil. In: Claudino-Sales V, organizer. Ecossistemas Brasileiros: Manejo e Conservação. Fortaleza: Expressão Gráfica e Editora; 2003. p. 209-216.

PILLAR VP, ANDRADE BO, DADALT L. Serviços ecossistêmicos. In: Pillar VP, Lange O, editors. Os Campos do Sul. Porto Alegre: Rede Campos Sulinos - UFRGS; 2015. p. 115119.

PINTO MP, NABINGER C, BOLDRINI II, FERREIRA PMA, SETUBAL RB, TREVISAN R et al. Floristic and vegetation structure of a grassland plant community on shallow basalt in southern Brazil. Acta Bot. Bras. 2013;27(1):162-179.

QUADROS FLF, PILLAR VD. Dinâmica vegetacional em pastagem natural submetida a tratamentos de queima e pastejo. Cienc. Rural. 2001; 31:863-868. 
QUADROS FLF, TRINDADE JPP, BORBA M. Abordagem funcional da ecologia campestre como instrumento de pesquisa e apropriação do conhecimento pelos produtores rurais. In: Pillar VD, Müller SC, Castilhos ZMS, Jacques AVA, editors. Campos Sulinos - Conservação e uso sustentável da Biodiversidade. Brasília: MMA; 2009. p. 206-213.

RAMBO B. A fisionomia do Rio Grande do Sul. Porto Alegre: Selbach; 1956.

RIBEIRO VLS, SANTOS JC, BORDIGNON SAL, APEL MA, HENRIQUES AT, VON POSER $\mathrm{GL}$. Acaricidal properties of the essential oil from Hesperozygis ringens (Lamiaceae) on the cattle tick Rhipicephalus (Boophilus) microplus. Bioresour. Technol. 2010; 101:2506-2509.

RIEDERER M, SCHREIBER L. Protecting against water loss: analysis of the barrier properties of plant cuticles. J. Exp. Bot. 2001; 52:2023-2032.

RIZZINI CT, HERINGER EP. Underground organs of plants from some southern Brazilian savannas, with special reference to xylopodium. Phyton. 1961;17(1):105-24.

ROCHA MDS, SILVA GLD, OLIVEIRA SJ, FREITAS, EM, FERLA NJ. Phytoseiid mites (Acari: Phytoseiidae) in the northern coastal region of the Rio Grande do Sul State, Brazil. Neotropical Biodiversity. 2015;1(1):22-35.

ROSA DM, FORTES AMT, PALMA D, MARQUES DS, CORSATO JM, LESZCZYNSKI R et al. Efeito dos extratos de tabaco, leucena e sabugueiro sobre a germinação de Panicum maximum Jaqc. R. bras. Bioci. 2007; 5:444-446.

ROVEDDER AP, ELTZ FLF, DRESCHER MS, SCHENATO RB, ANTONIOLLI ZI. Edaphic organisms as bioindicators of restoration of degraded soils by arenização on the Bioma Pampa. Cienc. Rural. 2009;39(4):1061-1068.

SAGE RF. Environmental and Evolutionary Preconditions for the Origin and Diversification of the C4 Photosynthetic Syndrome. Plant Biology. 2001; 3:202-213.

SAGE RF, CHRISTIN PA, EDWARDS EJ. The C4 plant lineages of planet Earth. J. Exp. Bot. 2011; 62:3155-3169.

SEMA. Portaria SEMA n 79, de 31 de Outubro de 2013. Reconhece a lista de Espécies Exóticas do Rio Grande do Sul. 2013. Disponível em http://www.institutohorus.org.br/download/marcos_legais/Portaria\%20SEMA\%20RS\% 2079\%20-\%202013\%20Lista\%20invasoras.pdf. Acesso em 31.08.2019.

SETUBAL RB, BOLDRINI II. Phytosociology and natural subtropical grassland communities on a granitic hill in southern Brazil. Rodriguésia. 2012;63(3):513-524.

SILVA LDB, MEDEIROS JD. Anatomia foliar comparativa de Psidium cattleyanum Sab. (Myrtaceae). Insula Botânica. 2005; 34:15-38. 
SILVA LL, SILVA DT, GARLET QI, CUNHA MA, MALLMANN CA, BALDISSEROTTO B et al. Anesthetic activity of Brazilian native plants in silver catfish (Rhamdia quelen). Neotrop. Ichthyol. 2013; 11:443-451.

SPEAR D, FOXCROFT LC, BEZUIDENHOUT H, MCGEOCH MA. Human population density explains alien species richness in protected areas. Biol. Conserv.. 2013; 159:137-147.

STRECK EV, KÄMPF N, DALMOLIN RSD, KLAMT E, NASCIMENTO PC, SCHNEIDER P et al. Solos do Rio Grande do Sul. 2a ed. Porto Alegre: EMATER/RS. 2008. p. 222.

SUERTEGARAY DMA. Deserto Grande do Sul: controvérsia. Porto Alegre: Editora da Universidade; 1998.

SUERTEGARAY DMA, GUASSELLI LA, VERDUM R. Atlas da Arenização: Sudoeste do Rio Grande do Sul. Porto Alegre: Secretaria da Coordenação e Planejamento; 2001.

TOLDI M, FERLA NJ, FERLA J, FREITAS EM, LILLO E. Four new species of eriophyoid mites (Acari: Trombidiformes: Eriophyoidea) on native vegetation from Pampa biome, in the state of Rio Grande do Sul (Brazil). Systematic \& Applied Acarology. 2019;24(6):977-991.

VALLS JFM, BOLDRINI II, LONGHI-WAGNER HM E MIOTTO STS. O patrimônio florístico dos campos: potencialidades de uso e a conservação de seus recursos genéticos. In: Pillar VD, Müller SC, Castilhos ZMS, Jacques AVA, editors. Campos Sulinos - Conservação e uso sustentável da Biodiversidade. Brasília: MMA; 2009. p. 129-154.

VELEZ-MARTIN E, ROCHA CH, BLANCO C, AZAMBUJA BO, HASENACK H, PILLAR VP. Conservação e fragmentação. In: Pillar VP, Lange O, editors. Os Campos do Sul. Porto Alegre: Rede Campos Sulinos - UFRGS; 2015. p. 123-133.

VERDUM R. Depressão Periférica e planalto. Potencial ecológico e utilização social da natureza. In: Verdum R, Basso LA, Suertegaray DMA, organizers. Rio Grande do Sul: paisagens e territórios em transformação. Porto Alegre: Editora da Universidade/UFRGS; 2004. p. 39-57.

VERDUM R. Paisagem do Pampa: monotonia que se rompe no espaço e no tempo. In: Chomenco L, Bencke GA, organizers. Nosso Pampa desconhecido. Porto Alegre: Fundação Zoobotânica do Rio Grande do Sul; 2016. 45-60.

VIANA A. Morfologia e anatomia foliar de espécies de angiosperma com ocorrência nos campos de areais do bioma Pampa [dissertation]; 2018. 45 p.

VON POSER GL, MENUT C, TOFFOLI ME, VÉRIN P, SOBRAL M, BESSIÉRIE JM et al. Essential oil composition and allelopathic effect of the Brazilian Lamiaceae 
Hesperozygis ringens (Benth.) Eplig and Hesperozygis rhododon Eplig. J. Agric. Food Chem. 1996; 44:1829-1832.

WAGNER MA, LOEUILLE BFP, SINISCALCHI CM, MELO-DE-PINNA GF, PIRANI JR. Diversity of non-glandular trichomes in subtribe Lychnophorinae (Asteraceae: Vernonieae) and taxonomic implications. Plant Syst Evol. 2014; 300:1219-1233. 